\title{
Analisis Dampak Surat Edaran Reformasi Birokrasi Nomor 34 Tahun 2020 Terhadap Kinerja Keuangan Perusahaan Sektor Telekomunikasi yang Terdaftar di Bursa Efek Indonesia \\ Fitra Oliyan1, Randy Heriyanto2
}

oliyan.fitra@gmail.com ${ }^{1}$. heriyantorandy@gmail.com ${ }^{2}$

Jurusan Akuntansi, Politeknik Negeri Padang1

Email:oliyan.fitra@gmail.com

Jurusan Akuntansi, Politeknik Negeri Padang2

Email:heriyantorandy@gmail.com

\begin{abstract}
ABSTRAK
Pada era ini, masyarakat memanfaatkan teknologi informasi dan komunikasi untuk melakukan aktivitas perdagangan baik barang ataupun jasa melalui internet. Bidang pendidikan juga mulai melakukan transisi dengan memberikan pendidikan dengan sistem pembelajaran dalam jaringan. Tahun 2020 merupakan tahun yang diselimuti dengan ketakutan akan pandemi COVID-19. Pandemi mengakibatkan pemerintah menganjurkan pihak Aparatur Sipil Negara untuk melakukan pekerjaan mereka dengan istilah "Work from Home". Peraturan ini tercantum dalam surat edaran reformasi birokrasi nomor 34 tahun 2020. Hal ini mengakibatkan pihak ASN yang selama ini diharuskan bekerja di Instansi masing-masing membawa pekerjaan mereka ke rumah. Sehingga mengharuskan mereka untuk memanfaatkan teknologi informasi dengan maksimal melalui internet. Perusahaan yang bergerak dalam fasilitas teknologi informasi memiliki keuntungan tersendiri dalam penyediaan layanan data. Dalam peniltian ini akan ditemukan apakah perbedaan kinerja keuangan pada perusahaan yang menyediakan fasilitas teknologi informasi ini yaitu sektor telekomunikasi.
\end{abstract}

Kata kunci: Telekomunikasi, Debt to Equity Ratio, Total Assets Turnover, Return on Assets.

\begin{abstract}
In this era, people use information and communication technology to carry out trading activities, both goods and services via the internet. The education sector is also starting to make a transition by providing education with an online learning system. 2020 is a year shrouded in fear of the COVID-19 pandemic. The pandemic resulted in the government encouraging the State Civil Service to carry out their work with the term "Work from Home". This regulation is stated in bureaucratic reform circular letter number 34 of 2020. This has resulted in ASN parties who have been required to work in their respective agencies to bring their work home. So that requires them to make maximum use of information technology via the internet. Companies engaged in information technology facilities have their own advantages in providing data services. In this research, it will be found whether the difference in financial performance of companies that provide information technology facilities is the telecommunications sector.
\end{abstract}

Kata kunci: Telecomunication, Debt to Equity Ratio, Total Assets Turnover, Return on Assets.

\section{Pengantar}

Dalam pelaksanaan analisis, tingkat pengembalian harus diperhatikan oleh para investor. Terdapat dua faktor yang mempengaruhi tingkat pengembalian suatu investasi, yaitu faktor internal dan eksternal. Dengan adanya analisis fundamental, kita bisa menganilisis faktor internal. Analisis historis atas kekuatan keuangan adalah dasarnya. Dalam melaksanakan analisis fundamental para investor seharusnya mempelajari laporan keuangan perusahaan, dengan tujuan untuk menganalisis kinerja perusahaan dengan mendapatkan peta kekuatan perusahaan, menilai efisiensi operasional serta 
mengetahui sifat dasar dan sifat khusus operasional perusahaan. Kinerja perusahaan itu sendiri tergambar dalam laporan keuangan perusahaan (Ang, 1997).

Rasio keuangan bisa digunakan dalam menganalisis kinerja keuangan yang terdiri dari beberapa rasio. Menurut Kasmir (2013) rasio keuangan terdiri dari enam rasio. Pertama, rasio profitabilitas yaitu rasio dalam menghasilkan laba. Kedua, rasio likuiditas yaitu rasio yang mengukur mengenai kemampuan dalam membayar kewajiban (utang) jangka pendek dengan aset lancar yang dimiliki. Ketiga, rasio solvabilitas yaitu mengukur kemampuan perusahaan dalam memenuhi seluruh liabilitas, dengan menggunakan seluruh ekuitasnya. Keempat, rasio aktifitas yaitu rasio untuk mengukur efektifitas perusahaan dalam memberdayakan aktiva yang dimilikinya. Kelima, rasio pertumbuhan yaitu rasio yang mengilustrasikan abilitas perusahaan dalam menjaga kestabilan perekonomian perusahaan. Keenam, rasio penilaian (valuation ratio) yaitu rasio yang memberikan ukuran kecakapan manajemen dalam memberikan nilai pasar usaha perusahaan.

Peneliti akan mengambil rasio profitabilitas, rasio likuiditas, dan rasio solvabilitas. Pemilihan ketiga rasio keuangan ini adalah untuk memperkirakan tingkat kesulitan keuangan perusahaan, hasil operasi, kondisi keuangan sekarang dan kedepannya, menggambarkan hasil kinerja manajemen, serta sebagai ukuran efektivitas investasi oleh investor. Alasan pemilihan ketiga rasio ini didukung oleh terdapatnya beberapa penelitian terdahulu yang menggunakan rasio yang sama seperti penelitian yang dilakukan oleh Abdullah dan Merdekawati (2015) yang menggunakan beberapa rasio keuangan untuk menentukan pengaruhnya terhadap return saham. Variabel rasio keuangan yang digunakan adalah ROA, ROE, CR, dan DER. Fitra (2016) memakai kinerja keuangan dan faktor makroekonomi berpengaruh terhadap return saham.

Pada Maret 2020 permerintah mengelurkan surat edaran reformasi birokrasi nomor 34 tahun 2020. Surat edaran ini dikeluarkan agar pandemi yang terjadi di Indonesia dan seluruh dunia yaitu COVID-19 bisa diminimalisir dampaknya (kematian akibat pandemi). Surat edaran ini dikeluarkan untuk mengatur seluruh ASN untuk bisa bekerja di rumah/work form home. Peraturan ini mengakibatkan masyarakat yang terdampak pada peraturan ini diharuskan memanfaat fasilitas teknologi informasi dengan memakai internet. Perusahaan dalam sektor telekomunikasi yang bertanggungjawab untuk penyediaan fasilitas ini. Apakah perusahaan dalam sektor ini bisa memanfaatkan kesempatan ini dalam meningkatkan nilai perusahan. Oleh karena itu peneliti memiliki keinginan untuk melihat gambaran atas kinerja keuangan pada sektor telekomunikasi.

\section{Analisis Deskriptif}

Perusahaan yang terdaftar dalam subsektor telekomunikas sebelum dan sesudah surat edaran reformasi birokrasi nomor 34 tahun 2020.

Tabel 1. Nama Perusahaan Subsektor Telekomunikasi

\begin{tabular}{|l|l|l|}
\hline No. & Kode & Nama Perusahaan \\
\hline 1 & BTEL & Bakrie Telecom Tbk. \\
\hline 2 & EXCL & XL Axiata Tbk. [S] \\
\hline 3 & FREN & Smartfren Telecom Tbk. [S] \\
\hline 4 & ISAT & Indosat Tbk. [S] \\
\hline 5 & JAST & Jasnita Telekomindo Tbk. [S] \\
\hline 6 & TLKM & Telekomunikasi Indonesia (Persero) Tbk. [S] \\
\hline
\end{tabular}


Perusahaan tersebut memiliki dampak langsung terhadap surat edaran reformasi birokrasi nomor 34 tahun 2020 yang telah dikeluarkan. Berikut data mengenai variabel terkait.

Tabel 2. Rasio Keuangan Perusahaan Quarter 1 Tahun 2020

\begin{tabular}{|l|l|l|l|l|l|}
\hline No. & Kode & Nama Perusahaan & D/E Ratio & TATO & ROA \\
\hline 1 & BTEL & Bakrie Telecom Tbk. & -1.05 & 0.008286 & -56.5 \\
\hline 2 & EXCL & XL Axiata Tbk. [S] & 2.28 & 0.415065 & 1.14 \\
\hline 3 & FREN & Smartfren Telecom Tbk. [S] & 1.17 & 0.263614 & -10.5 \\
\hline 4 & ISAT & Indosat Tbk. [S] & 3.58 & 0.440156 & 2.5 \\
\hline 5 & JAST & Jasnita Telekomindo Tbk. [S] & 0.79 & 0.454545 & -1.19 \\
\hline 6 & TLKM & Telekomunikasi Indonesia (Persero) Tbk. [S] & 0.85 & 0.47659 & 10.2 \\
\hline
\end{tabular}

Tabel 3. Rasio Keuangan Perusahaan Quarter 2 Tahun 2020

\begin{tabular}{|l|l|l|l|l|l|}
\hline No. & Kode & Nama Perusahaan & D/E Ratio & TATO & ROA \\
\hline 1 & BTEL & Bakrie Telecom Tbk. & -1.05 & 0.008291 & -56.5 \\
\hline 2 & EXCL & XL Axiata Tbk. [S] & 2.46 & 0.096799 & 8.5 \\
\hline 3 & FREN & Smartfren Telecom Tbk. [S] & 2.02 & 0.065724 & -21.5 \\
\hline 4 & ISAT & Indosat Tbk. [S] & 3.63 & 0.105472 & -3.98 \\
\hline 5 & JAST & Jasnita Telekomindo Tbk. [S] & 0.74 & 0.100671 & -9.25 \\
\hline 6 & TLKM & Telekomunikasi Indonesia (Persero) Tbk. [S] & 0.91 & 0.149677 & 9.69 \\
\hline
\end{tabular}

Dari data tersebut akan diolah menjadi uji beda, apakah dampak setelah terbitnya surat edaran reformasi birokrasi nomor 34 tahun 2020 di tahun 2020. Data akan diolah menggunakan uji beda Mann Whitney, hal ini dilakukan karena variabel yang diuji merupakan bentuk skala rasio dan data juga tidak diperlukan dalam keadaan berdistribusi normal namun dalam kemiringan yang sama.

\section{Uji Beda Mann Whitney U Test Pada Quarter Satu Dan Quarter Dua}

\section{Debt to Equity Ratio}

Kesamaan bentuk atau penyebaran data terlihat dari Rasio Skewness yang bisa dicari dengan skewness dibagi dengan standar error skewness. Rasio skewness dari rasio Debt to Equity Ratio pada quarter 1 adalah 0.06 dan pada quarter 2 adalah -0.38 . Ini menunjukkan bahwa kedua data yang diuji memiliki penyebaran data yang sama

Hasil uji beda Debt to Equity Ratio

Tabel 4. Mean DER

\begin{tabular}{|ll|l|l|l|}
\hline \multicolumn{2}{|c|}{ Quarter } & N & Mean Rank & Sum of Ranks \\
\hline DER & Quarter 1 & 6 & 6.25 & 37.50 \\
& Quarter 2 & 6 & 6.75 & 40.50 \\
& Total & 12 & & \\
\hline
\end{tabular}


Tabel 5. Hasi Uji Beda Mann Whitney DER

\begin{tabular}{|l|l|}
\hline & DER \\
\hline Mann-Whitney U & 16.500 \\
Wilcoxon W & 37.500 \\
$Z$ & -.241 \\
Asymp. Sig. (2-tailed) & .810 \\
Exact Sig. [2*(1-tailed Sig.)] & $.818^{\mathrm{a}}$ \\
\hline
\end{tabular}

a. Not corrected for ties.

b. Grouping Variable: Quarter

Dari hasi tersebut bisa dilihat Asymp. Sig (2-tailed) lebih besar dari 0,05. Ini berarti perusahaan yang ada menanggung tingkat hutang yang relatif sama dari quarter 1 dan quarter 2. Perusahaan - perusahaan tidak terdampak akan kebijakan POJK dari segi tingkat hutang.

\section{Total Asset Turn Over}

Hasil Rasio Skewness pada quarter 1 adalah -1.98 dan quarter 2 adalah -0.89. Ini menunjukkan data memiliki kemiringan yang sama.

Hasil uji beda Total Assets Turnover

Tabel 6. Mean TATO

\begin{tabular}{|ll|l|l|l|}
\hline \multicolumn{2}{|c|}{ Quarter } & N & Mean Rank & Sum of Ranks \\
\hline TATO & Quarter 1 & 6 & 8.50 & 51.00 \\
& Quarter 2 & 6 & 4.50 & 27.00 \\
& Total & 12 & & \\
\hline
\end{tabular}

Tabel 7. Hasil Uji Beda Mann Whitney TATO

\begin{tabular}{|l|l|}
\hline & TATO \\
\hline Mann-Whitney U & 6.000 \\
Wilcoxon W & 27.000 \\
$Z$ & -1.922 \\
Asymp. Sig. (2-tailed) & .050 \\
Exact Sig. [2*(1-tailed Sig.)] & $.065^{\mathrm{a}}$ \\
\hline a. Not corrected for ties. \\
b. Grouping Variable: Quarter
\end{tabular}

Dari data tersebut Asymp. Sig. (2-tailed) signifikan pada 0.05. Pendapatan dari perusahaan - perusahaan yang bergerak di bidang subsektor telekomunikasi mengalami penurunan yang drastis hampir 50\%.

\section{Return On Assets}

Hasil dari rasio skewness pada quarter 1 adalah -2.42 dan quarter 2 adalah -1.61. ini menunjukkan bahwa penyebaran data dari ROA adalah di rentang penyebaran yang sama. 


\section{Hasil uji beda Rerturn On Assets}

Tabel 8. Mean ROA

\begin{tabular}{|ll|l|l|l|}
\hline \multicolumn{2}{|c|}{ Quarter } & N & Mean Rank & Sum of Ranks \\
\hline ROA & Quarter 1 & 6 & 6.92 & 41.50 \\
& Quarter 2 & 6 & 6.08 & 36.50 \\
& Total & 12 & & \\
\hline
\end{tabular}

Tabel 9. Hasil Uji Beda Mann Whitney ROA

\begin{tabular}{l|l|}
\hline & ROA \\
\hline Mann-Whitney U & 15.500 \\
Wilcoxon W & 36.500 \\
$Z$ & -.401 \\
Asymp. Sig. (2-tailed) & .688 \\
Exact Sig. [2*(1-tailed Sig.)] & $.699 \mathrm{a}$ \\
\hline a. Not corrected for ties. \\
b. Grouping Variable: Quarter
\end{tabular}

Hasil dari Asymp. Sig. (2-tailed) lebih besar dari 0.05. Ini menunjukkan bahwa perusahaan -perusahaan yang bergerak di subsektor financial institution masih mampu mengelola asetnya untuk menghasilkan keuntungan dengan efisien. Hal ini terlihat dari rata - rata ROA dari quarter 1 dan 2 tidak mengalami penurunnan yang drastis.

\section{Kesimpulan}

Penilitian bertujuan untuk mengetahui seberapa besar dampak perkonomian pada masyarakat. Hal yang mendasari penilitan ini adalah adanya surat edaran reformasi birokrasi nomor 34 tahun 2020. Ini menyebabkan banyak aktivitas dilakukan melalui dalam jaringan. Subsektor telekomunikasi menyediakan fasilitas jaringan internet yang bisa dibeli oleh masyarakat. Apakah hal ini akan mempengaruhi keadaan perekonomian dari subsektor telekomunikasi? Hasil dari penilitian ini dapa disimpulkan bahwa:

1. Debt to Equity Ratio, dari segi ini tidak terjadi perubahan yang signifikan. Perusahaan - perusahaan masih memiliki tingkat hutang yang masih sama dari sebelum dan sesudah penerapan dari surat edaran reformasi birokrasi nomor 34 tahun 2020.

2. Total Asset Turn Over, dari segi ini bisa terlihat bahwa terjadi penurunan yang signifikan. Pendapatan di subsektor telekomunikasi yang ternyata tidak berimbas positif di quarter ke 2 tahun 2020.

3. Return on Assets, dari segi ini subsektor telekomunikasi masih bisa mengelola asetnya secara efisien. 


\section{Referensi}

[1] Fahmi, Irham. 2011. Analisis Laporan Keuangan. Lampulo: ALFABETA.

[2] Harahap, S. S. .2007. Analisis Krirtis Atas Laporan Keuangan. Jakarta: PT.Raja Grasindo Persada

[3] Jumingan. 2006. Analisis Laporan Keuangan, Cetakan Pertama, PT Bumi Aksara, Jakarta.

[4] Munawir, S. 2012. Analisis Informasi Keuangan, Liberty, Yogyakarta.

[5] NICRD. 2020. "Social Distancing, Quarantine, and Isolation.” Retrieved April 1, 2020 (https://www.cdc.gov/coronavirus/2019-ncov/prevent-getting-sick/socialdistancing.html).

[6] Oliyan, Fitra. 2016. Pengaruh Kinerja Keuangan Perusahaan Dan Faktor Makroekonomi Terhadap Return Saham Perusahaan Yang Terdaftar Di Bursa Efek Indonesia Periode 2010-2014 (Doctoral Dissertation, Universitas Andalas).

[7] Oliyan, Fitra. 2013. Analisa Tingkat Pengembalian Investor Lokal Dan Investor Asing Dengan Menggunakan Pendekatan Disposition Effect (Doctoral Dissertation, Politeknik Negeri Padang).

[8] Rizka. 2020. “Arti Social Distancing Dan Physical Distancing, Apa Bedanya?” Retrieved April 1, 2020 (https://www.indozone.id/life/WYsAgk/perbedaan-socialdistancing-dan-physical-distancing/read-all).

[9] Sutrisno. 2009. Manajemen Keuangan Teori, Konsep dan Aplikasi. Ekonisia, Yogyakarta. 